\title{
Transition Characteristics and Risk Assessment of Heavy Metal(loid)s in Barley (Hordeum vulgare L.) Grown at the Major Producing Districts in Korea
}

\begin{abstract}
Da-Young $\mathrm{Kim}^{1 \dagger}{ }^{\dagger}$, Won-Il Kim ${ }^{\dagger}$, Ji-Hyock $\mathrm{Yoo}^{3}$, Oh-Kyung Kwon ${ }^{4}$ and Il Kyu Cho ${ }^{2^{\star}}$
${ }^{1}$ Department of Environmental Horticulture, University of Seoul, Seoul 02504, Korea, ${ }^{2}$ Eco-Friendly Agri-Bio Research Center, Jeonnam Bioindustry Foundation, Gokseong 57510, Korea, ${ }^{3}$ Residual Agrochemical Assessment Division, National Institute of Agricultural Science, Wanju 55365, Korea, ${ }^{4}$ OJEong Resilience Institute, Korea University, Seoul 02841, Korea

Received: 12 February 2021/ Revised: 3 March 2021/ Accepted: 24 March 2021

Copyright (c) 2021 The Korean Society of Environmental Agriculture

This is an Open-Access article distributed under the terms of the Creative Commons Attribution Non-Commercial License (http://creativecommons.org/licenses/by-nc/3.0) which permits unrestricted non-commercial use, distribution, and reproduction in any medium, provided the original work is properly cited.
\end{abstract}

ORCID

Da-Young Kim

http://orcid.org/0000-0003-3998-9058

Won-II Kim

http://orcid.org/0000-0003-4692-8667

Ji-Hyock Yoo

http://orcid.org/0000-0003-2007-5790
Oh-Kyung Kwon

http://orcid.org/0000-0003-0737-5422

II Kyu Cho

http://orcid.org/0000-0002-4177-5588

barley $\mathrm{Pb}$ is set at $0.2 \mathrm{mg} \mathrm{kg}^{-1}$ in Korea, and the monitoring results suggested that some samples exceeded the maximum allowable level and required appropriate farming management. Bio-concentration factor values by heavy metal(loid)s in barley were high at $\mathrm{Cd}$, copper $(\mathrm{Cu})$ and zinc $(\mathrm{Zn})$, similar to other crops, while $\mathrm{As}$ and $\mathrm{Pb}$ were low, indicating low transferability.

CONCLUSION: Human exposure to $\mathrm{As}, \mathrm{Cd}$ and $\mathrm{Pb}$ through dietary intake of barley might not cause adverse health effects due to relatively low concentrations, although the $\mathrm{Pb}$ in some barley was detected higher than the maximum allowable level. Further study on uptake and accumulation mechanism of $\mathrm{Pb}$ by barley might be required to assess the human health risk associated with soil contamination.

Key words: Barley, Heavy Metal(loid)s, Lead, Monitoring, Risk Assessment

\section{Introduction}

As the quality of life improves, interest in agricultural product safety is also increasing. Continuously, 
crop cultivation environment and criteria related to heavy metal(loid)s in agricultural products are expanded and supplemented. Therefore, a review of advanced data and scientific risk assessment is required. The Food and Agricultural Organization (FAO) and the World Health Organization (WHO) designated heavy metal(loid) in agricultural crops as monitoring pollutants as well as managed them safety. Among these heavy metal(loid)s in crops, there are remarkably damaging such as mercury $(\mathrm{Hg})$, cadmium $(\mathrm{Cd})$, lead $(\mathrm{Pb})$ and arsenic (As) even in insignificant quantities.

Barley, one of the largest cereal grains around the world, is the second staple food in Korea and grown in winter used for food and forage purposes. Moreover, there are substantial economic benefits for healthy food and alcohol production using beta-glucan that could be found in whole grain [1]. In the re-evaluation report on the standard of heavy metal(loid)s in food in Korea in 2017, the concentrations of heavy metals in barley and brown rice were $0.0118 \mathrm{mg} \mathrm{kg}^{-1}, 0.0035$ $\mathrm{mg} \mathrm{kg}^{-1}$ for Pd, and $0.021 \mathrm{mg} \mathrm{kg}^{-1}, 0.0124 \mathrm{mg} \mathrm{kg}^{-1}$ for $\mathrm{Cd}$, respectively, which showed highly those in barley than brown rice. However, the concentration of As in barley $\left(0.011 \mathrm{mg} \mathrm{kg}^{-1}\right)$ was remarkably lower than that of As in brown rice $\left(0.101 \mathrm{mg} \mathrm{kg}^{-1}\right)$. Nevertheless, the exposure of rice and barley to heavy metals is not high compared to other grains. In Korea, naturally, rice is cultivated from spring to fall, and barley is cultivated in the same paddy field from fall to the next spring. Although they are grown in the same soil, the reason that barley has a higher concentration of heavy metal(loid)s than rice may be differences in the absorption properties of crops. [2] showed that soil physicochemical factors (such as $\mathrm{pH}$, cation exchange capacity, clay content) influence the accumulation of $\mathrm{Pb}$ in various parts of barley in contaminated soil by $\mathrm{Pb}$ from traffic pollution. Likely, [3] reported that the average lead concentration in barley $\left(0.136 \mathrm{mg} \mathrm{kg}^{-1}\right)$ was higher than rice $\left(0.099 \mathrm{mg} \mathrm{kg}^{-1}\right)$, some of which exceeded the maximum residual levels (MLs) of lead $\left(0.2 \mathrm{mg} \mathrm{kg}^{-1}\right)$ established by the Codex, requiring continuous monitoring. In this study, in order to investigate the characteristics of transition from soil to barley, we evaluated human risks and suggested management for safe production of agricultural products through monitoring the heavy metal(loid)s of cultivated soil and barley in the major producing district in Korea

\section{Materials and Methods}

\section{Sampling Site and Preparation}

Agricultural soil and barley samples were collected at Jeokkabuk-do province in Korea (e.g., Gunsan, Gimje, Jeongeup, Jeonju, etc.) from May to June 2019. Both plants and soil were sampled at the same point. All soil samples were air-dried, crumbled and passed through a $2 \mathrm{~mm}$ sieve. For the analysis of heavy metal(loid)s in soil, samples were ground to $<0.074 \mathrm{~mm}$. Barley samples were dried at $60^{\circ} \mathrm{C}$ for a day. The air-dried barley was polished with rice barley using the experimental mill (SY21F, Sang Yong Inc, Korea), and then powdered homogenously for analysis. The thirty-four of the barley samples were collected at market for additional analysis.

\section{Heavy Metal(loid)s Analysis in Soil and Barley}

The analysis of heavy metals contents in soil were performed with the guideline of the Korean Ministry of the Environment (MOE) using an inductively coupled plasma-optical emission spectrophotometer (ICPOES). Three grams of sieved soil was digested with aqua regia, $21 \mathrm{~mL} \mathrm{HCl}+7 \mathrm{~mL} \mathrm{HNO}_{3}$ (3:1) using Kjeldatherm (C. Gerhardt $\mathrm{GmbH} \& \mathrm{Co} .$, Northants, UK) at $30^{\circ} \mathrm{C}$ for $2 \mathrm{~h}$, and then heated at $90^{\circ} \mathrm{C}$ for $2 \mathrm{~h}$. After filtering, samples were adjusted to a final volume of $100 \mathrm{~mL}$ with $0.5 \mathrm{M} \mathrm{HNO}_{3}$.

The barley samples of about 0.25-0.5 g transferred into teflon vessel were digested with $8 \mathrm{~mL} 62 \% \mathrm{HNO}_{3}$ $1 \mathrm{~mL} \mathrm{H}_{2} \mathrm{O}_{2}$ using microwave digestion system (ETHOS, Milestone, Italy) at $200^{\circ} \mathrm{C}$ for 20 minutes, continuously adjusted to a volume $20 \mathrm{~mL}$ with deionized water, and then filtered with $0.45 \mu \mathrm{m}$ membrane filter. After that, the concentration of heavy metal(loid)s was analyzed by ICP-MS (Agilent Technologies, 7500a). The recovery test for elements were verified, obtaining recovery values between 81.4 and $100.3 \%$ for every heavy metal(loid)s analyzed.

\section{Estimated BCF and Assessed Human Health Risk}

The bio-concentration factor (BCF) was calculated using Eq. (1). It is the ratio of the concentration of heavy metal in plant compared to that in soil [3].

$$
\begin{aligned}
\mathrm{BCF}= & \text { Heavy metal in barley }\left(\mathrm{mg} \mathrm{kg}^{-1} \mathrm{DW}\right) / \\
& \text { Heavy metal in soil }\left(\mathrm{mg} \mathrm{kg}^{-1}\right)
\end{aligned}
$$

The CR (Cancer risk probability) and HQ values 
Table 1. Total contents of heavy metal(loid)s in soil grown at the major producing districts of barley in Korea

\begin{tabular}{|c|c|c|c|c|c|c|}
\hline \multirow{2}{*}{ Items } & As & $\mathrm{Cd}$ & $\mathrm{Cu}$ & $\mathrm{Ni}$ & $\mathrm{Pb}$ & $\mathrm{Zn}$ \\
\hline & \multicolumn{6}{|c|}{$\mathrm{mg} \mathrm{kg}^{-1}$} \\
\hline Mean & 9.59 & 0.28 & 22.4 & 28.2 & 57.9 & 81.6 \\
\hline SD & 5.67 & 0.23 & 4.4 & 5.5 & 13.9 & 18.0 \\
\hline Min & 2.70 & 0.01 & 14.6 & 20.9 & 36.4 & 58.6 \\
\hline Max & 24.53 & 1.10 & 35.5 & 43.3 & 83.1 & 132.4 \\
\hline Median & 8.70 & 0.25 & 22.4 & 28.2 & 61.6 & 76.7 \\
\hline $95 \mathrm{P}$ & 19.37 & 0.52 & 28.0 & 35.7 & 75.8 & 120.5 \\
\hline 2015 data $^{\dagger}$ & 4.41 & 0.25 & 13.2 & 13.6 & 21.3 & 54.1 \\
\hline Concern level $^{\dagger \dagger}$ & 25 & 4 & 150 & 100 & 200 & 300 \\
\hline
\end{tabular}

${ }^{\dagger}$ Average content of heavy metal(loid)s in non-contaminated paddy soil in Korea [7]

${ }^{\dagger \dagger}$ Concern levels for soil contamination described in Soil Environmental Conservation Act

Table 2. Total concentrations of heavy metal(loid)s in barley grown at the major producing districts in Korea

\begin{tabular}{|c|c|c|c|c|c|c|}
\hline \multirow{2}{*}{ Items } & As & $\mathrm{Cd}$ & $\mathrm{Cu}$ & $\mathrm{Ni}$ & $\mathrm{Pb}$ & $\mathrm{Zn}$ \\
\hline & \multicolumn{6}{|c|}{$\mathrm{mg} \mathrm{kg}^{-1} \mathrm{DW}$} \\
\hline Mean & 0.037 & 0.028 & 4.559 & 0.756 & 0.137 & 27.946 \\
\hline SD & 0.017 & 0.019 & 1.004 & 0.166 & 0.025 & 5.998 \\
\hline Min & 0.016 & 0.004 & 3.216 & 0.643 & 0.107 & 17.858 \\
\hline Max & 0.094 & 0.083 & 8.022 & 1.568 & 0.212 & 44.149 \\
\hline Median & 0.034 & 0.025 & 4.445 & 0.719 & 0.130 & 26.151 \\
\hline $95 \mathrm{P}$ & 0.071 & 0.057 & 6.539 & 1.032 & 0.185 & 39.084 \\
\hline 2012 data $^{\dagger}$ & $\begin{array}{c}0.017 \\
(0.004 \sim 0.050)\end{array}$ & $\begin{array}{c}0.018 \\
(0.005 \sim 0.051)\end{array}$ & - & - & $\begin{array}{c}0.136 \\
(0.034 \sim 0.407)\end{array}$ & - \\
\hline Criteria $^{\dagger \dagger}$ & - & 0.1 & - & - & 0.2 & - \\
\hline
\end{tabular}

${ }^{\dagger}$ Average content of heavy metal(loid)s in barley collected at the non-contaminated paddy soil in Korea [3]

${ }^{\dagger \dagger}$ Maximum allowable level (DW basis) of heavy metal(loid)s in barley enforced by Food Sanitation Act

(Hazard Quotient) were obtained from the average daily dose (ADD). ADD can be estimated from the heavy metal(loid)s concentration in barley to assess human health risk using the following Eq. (2) [4-6].

$$
\begin{aligned}
& \mathrm{ADD}=\mathrm{C} \times \mathrm{IR} \times \mathrm{ED} \times \mathrm{EF} /(\mathrm{BW} \times \mathrm{AT} \times 365)(\mathrm{Eq} .2) \\
& \mathrm{C}=\text { Conc. of } \mathrm{As}, \mathrm{Cd}, \mathrm{Pb} \text { in barley }\left(\mathrm{mg} \mathrm{kg}^{-1} \mathrm{DW}\right) \\
& \mathrm{IR}=\text { Intake rate of crop }(0.00575 \mathrm{~kg} \text { day- } 1) \\
& \mathrm{ED}=\text { Exposure duration (30 years) } \\
& \mathrm{EF}=\text { Exposure frequency (365-day year-1) } \\
& \mathrm{BW}=\text { Body weight }(72.3 \mathrm{~kg}) \\
& \mathrm{AT}=\text { Averaging time (78 years) } \\
& \mathrm{CR}=\mathrm{ADD} \times \mathrm{SF} \\
& \mathrm{SF}=\text { Slope factor }\left(1.5 \mathrm{mg} \mathrm{kg}^{-1} \mathrm{day}^{-1}\right. \text { for As) } \\
& \mathrm{HQ}=\mathrm{ADD} / \mathrm{RfD}-- \text { (Eq. 4) } \\
& \mathrm{RfD}=\text { Reference dose }\left(0.0003 \mathrm{~kg}^{-1} \mathrm{day}^{-1} \text { for As, } 0.004\right. \\
& \mathrm{kg}^{-1} \text { day }^{-1} \text { for } \mathrm{Pb}, 0.001 \mathrm{~kg}^{-1} \text { day }^{-1} \text { for } \mathrm{Cd} \text { ) }
\end{aligned}
$$

\section{Results and Discussion}

Total metal(loid) contents in 38 soils are given in Table 1. The average contents and ranges of As, $\mathrm{Cd}$, $\mathrm{Cu}, \mathrm{Ni}, \mathrm{Pb}$, and $\mathrm{Zn}$ in soils were from 9.59 (2.70-24.53), 0.28 (0.01-1.10), $22.4(14.6-35.5), 28.2(20.9-43.3), 57.9$ (36.4-83.1) and 81.6 (58.6-132.4) $\mathrm{mg} \mathrm{kg}^{-1}$, respectively. The mean contents of heavy metal(loid)s were below the maximum allowable level of MOE, which was approximately 1/3 1/13 times lower. For the As content, it was slightly higher than the average As content of non-contaminated paddy soils $\left(4.41 \mathrm{mg} \mathrm{kg}^{-1}\right)$ [7]. Other elements showed similar results or slightly higher tendency [7].

Table 2 shows heavy metal(loid)s in 38 barley collected at the major producing districts in Korea. The $\mathrm{Cd}$ concentrations of barley were in the range of 0.004$0.083 \mathrm{mg} \mathrm{kg}^{-1}$, those were not exceeded the maximum 
Table 3. Total concentrations of heavy metal(loid)s in barley commercially purchased at the market in Korea

\begin{tabular}{|c|c|c|c|c|c|c|}
\hline \multirow{2}{*}{ Items } & As & $\mathrm{Cd}$ & $\mathrm{Cu}$ & $\mathrm{Ni}$ & $\mathrm{Pb}$ & $\mathrm{Zn}$ \\
\hline & \multicolumn{6}{|c|}{$\mathrm{mg} \mathrm{kg}^{-1} \mathrm{DW}$} \\
\hline Mean & 0.036 & 0.017 & 2.968 & 1.268 & 0.057 & 15.369 \\
\hline SD & 0.041 & 0.004 & 0.582 & 0.568 & 0.022 & 5.038 \\
\hline Min & 0.004 & 0.010 & 2.029 & 0.487 & 0.025 & 10.401 \\
\hline Max & 0.183 & 0.026 & 4.772 & 2.373 & 0.136 & 33.773 \\
\hline Median & 0.020 & 0.016 & 3.011 & 0.998 & 0.055 & 13.862 \\
\hline $95 \mathrm{P}$ & 0.135 & 0.022 & 3.929 & 2.199 & 0.094 & 23.177 \\
\hline 2017 data $^{\dagger}$ & $\begin{array}{c}0.011 \\
\text { (nd 0.101) }\end{array}$ & $\begin{array}{c}0.021 \\
(0.009 \sim 0.060)\end{array}$ & - & - & $\begin{array}{c}0.012 \\
\text { (nd } \sim 0.089 \text { ) }\end{array}$ & - \\
\hline Criteria $^{\dagger \dagger}$ & - & 0.1 & - & - & 0.2 & - \\
\hline
\end{tabular}

${ }^{\dagger}$ Average content of heavy metal(loid)s in barley collected at the markets in Korea

${ }^{\dagger \dagger}$ Maximum allowable level (DW basis) of heavy metal(loid)s in barley enforced by Food Sanitation Act

allowable level of $\mathrm{Cd}\left(0.1 \mathrm{mg} \mathrm{kg}^{-1}\right)$. On the contrary, the maximum $\mathrm{Pb}$ concentration of $0.212 \mathrm{mg} \mathrm{kg}^{-1}$ was observed in barley, which exceeds the maximum allowable level in barley. Besides, those values were similar to the previous study in that the $\mathrm{Pb}$ contents in barley range of $0.034-0.041 \mathrm{mg} \mathrm{kg}^{-1}$ [3]. The As concentrations varied from $0.016 \mathrm{mg} \mathrm{kg}^{-1}$ to $0.094 \mathrm{mg} \mathrm{kg}^{-1}$ among these plants, which was similar to the previous study in the As concentration in barley range from $0.004 \mathrm{mg} \mathrm{kg}^{-1}$ to $0.050 \mathrm{mg} \mathrm{kg}^{-1}$. Even though rice and barley plants are grown in similar cultivation fields, the As level was higher in rice and the $\mathrm{Cd}$ and $\mathrm{Pb}$ levels were higher in barley [3]. This may result in the difference between the absorption characteristic of barley and rice plant and water management practices, for example, rice cultivated in irrigated water and barley cultivated in non-irrigated water. The alternate wetting drying (AWD) and row treatment reduced the As level in brown rice by $32-60 \%$ but increased the $\mathrm{Cd}$ level [8]. This result shows that heavy metal(loid)s can be reduced through water management during the harvest season. In addition, crops grown under the same soil conditions may have different levels of accumulation due to their different resistance and affinity to each heavy metal $[9,10]$. [11] also reported that the difference in the level of heavy metal absorption of wheat and barley growing under the same conditions was due to the surrounding environment of the crop, competition and concentration between heavy metals, and the affinity for heavy metal ions of the crop.

The heavy metal(loid) concentrations of barley collected at the market were presented in Table 3. The average concentration and range of $\mathrm{As}, \mathrm{Cd}$, and $\mathrm{Pb}$ in barley were found to be 0.036 (0.004-0.183), 0.017 (0.010-0.026), and $0.057(0.025-0.136) \mathrm{mg} \mathrm{kg}^{-1}$, showing the maximum allowable level below the Food Sanitation Law in Korea. It was confirmed that the average and range of $\mathrm{As}, \mathrm{Cd}$ and $\mathrm{Pb}$ concentration in barley, which were investigated by the Ministry of Food and Drug Safety, differs from 0.011 (nd-0.1014), 0.0209 (0.0091-0.0603) and 0.0118 (nd-0.082) $\mathrm{mg} \mathrm{kg}^{-1}$, respectively, but had a similar concentration range. In addition, the fact that the heavy metal content of the market barley was lower than that of the major producing district could be estimated as the dilution of the heavy metal concentration of the market barley, which was mostly distributed at low concentration and diluted as well.

The concentrations of $\mathrm{Cd}$ and $\mathrm{Pb}$ in barley collected by distance from the highway passing through the major producing district in Korea were shown in Fig. 1. According to a survey of highway separation distances of up to 300 meters or more, $\mathrm{Cd}$ and $\mathrm{Pb}$ concentration in barley were believed to be rarely affected by highways. In general, as the distance from the highway increases, the content of $\mathrm{Cd}$ and $\mathrm{Pb}$ in the soil decreases estimating to be the effect of the highway. However, there is no significant difference between two variables (Fig. 2). In addition, higher contents of $\mathrm{Cd}$ and $\mathrm{Pb}$ in soil tend to increase the $\mathrm{Cd}$ and $\mathrm{Pb}$ concentration in barley, but significant differences between two variables are also not. The $\mathrm{Pb}$ concentration of some samples of barley earlier exceeds the standard and is expected to flow pollutants from the road as another factor. $[12,13]$ reported that the concentration of heavy metals in the soil collected within $5 \mathrm{~m}$ of the 

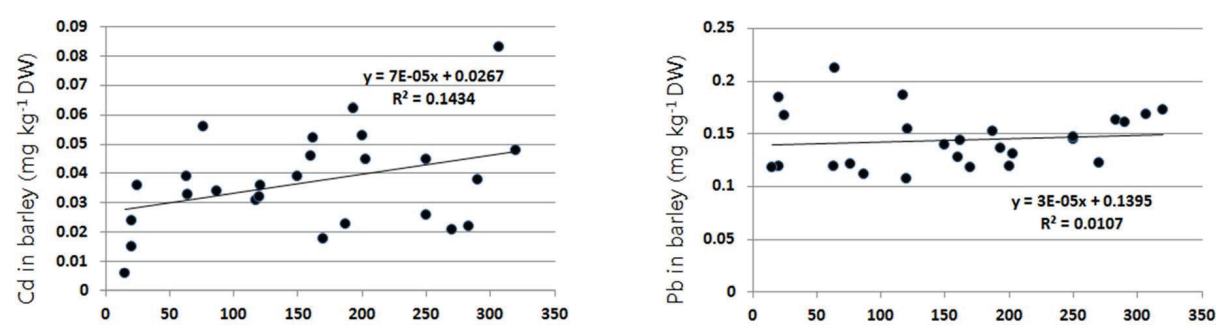

Fig. 1. $\mathrm{Cd}$ and $\mathrm{Pb}$ concentration $\left(\mathrm{mg} \mathrm{kg}^{-1} \mathrm{DW}\right)$ in barley grown by distance from highway.
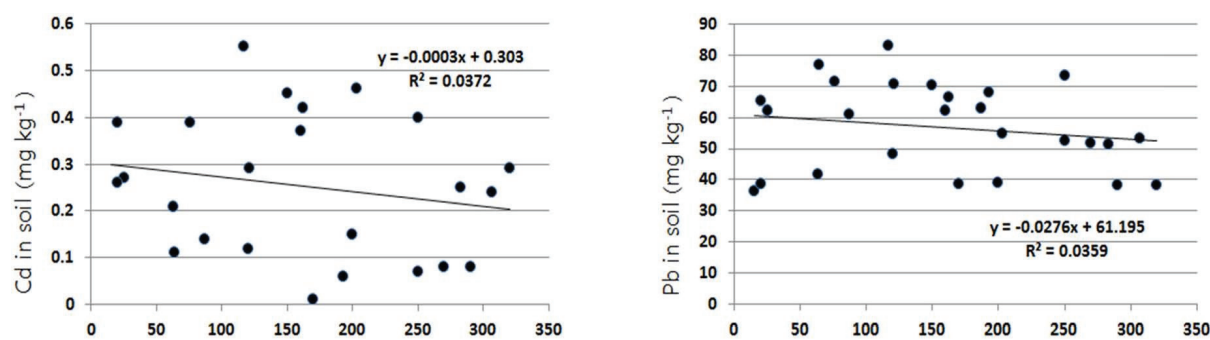

Fig. 2. $\mathrm{Cd}$ and $\mathrm{Pb}$ content $\left(\mathrm{mg} \mathrm{kg}^{-1}\right)$ in soil by distance from highway.
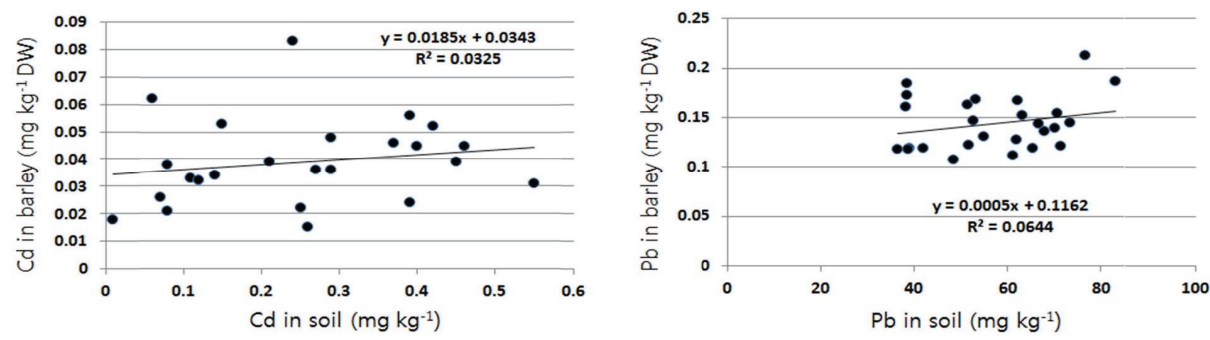

Fig. 3. The correlation of $\mathrm{Cd}$ and $\mathrm{Pb}$ between barley and soil located south western part of Korea.

Table 4. Bio-concentration factor (BCF) of heavy metal(loid)s in barley grown at the major producing districts in Korea

\begin{tabular}{cccccccc}
\hline Items & $\mathrm{As}$ & $\mathrm{Cd}$ & $\mathrm{Cu}$ & $\mathrm{Ni}$ & $\mathrm{Pb}$ & $\mathrm{Zn}$ \\
\hline Mean & 0.006 & 0.165 & 0.206 & 0.029 & 0.002 & 0.314 \\
SD & 0.006 & 0.128 & 0.053 & 0.006 & 0.001 & 0.098 \\
Min & 0.002 & 0.005 & 0.123 & 0.017 & 0.001 & 0.166 \\
Max & 0.025 & 0.507 & 0.368 & 0.047 & 0.005 & 0.635 \\
Median & 0.004 & 0.125 & 0.195 & 0.031 & 0.002 & 0.309 \\
95P & 0.017 & 0.363 & 0.303 & 0.038 & 0.004 & 0.491 \\
\hline
\end{tabular}

road was higher than that of soil collected in the dist ance. In addition, similar results were found in plants collected from the same site, which were estimated to be accumulated due to lower soil acidity and increased plant-based efficacy of heavy metals in agricultural areas near roads. [14] reported that the concentration of $\mathrm{Pb}$ in the soil more than $80 \mathrm{~m}$ from the road was not affected by the road, and the concentration of $\mathrm{Pb}$ in barley was not affected by the road.

Bio-concentration factors (BCF) of heavy metal(loid)s in barley grown at the major producing districts in Korea were given in Table 4 . The mean and range of the $\mathrm{BCF}$ of As was 0.006 (0.002-0.025). In comparison with other crops, the BCF of As in barley was relatively low compared to 0.101 for rice, which is high [3]. This is consistent with the relative inhibition of uptake compared to the state of reduction due to flooding condition. The mean and range of the BCF of $\mathrm{Cd}$ was 0.165 and 0.005-0.507, respectively. The level was higher than the $\mathrm{BCF}$ of the brown rice, 0.121 , which was esti- 
Table 5. Mean and maximum value of $\mathrm{HQ}$ and $\mathrm{CR}$ for $\mathrm{As}, \mathrm{Cd}$ and $\mathrm{Pb}$ concentrations in barley cultivated at the major producing districts and purchased on the market in Korea

\begin{tabular}{lcccccc}
\hline & & \multicolumn{2}{c}{ Hazard quotients $(\mathrm{HQ})$} & \multicolumn{2}{c}{ Cancer risk } \\
& As & Cd & Pb & Total & (CR) \\
\hline \multirow{2}{*}{ Cultivated barley } & $4.57 \times 10^{-3}$ & $9.85 \times 10^{-4}$ & $1.21 \times 10^{-3}$ & $6.76 \times 10^{-2}$ & $2.06 \times 10^{-6}$ \\
& $\left(2.11 \times 10^{-2}\right)^{\S}$ & $\left(2.92 \times 10^{-3}\right)$ & $\left(1.87 \times 10^{-2}\right)$ & $\left(2.59 \times 10^{-1}\right)$ & $\left(9.50 \times 10^{-6}\right)$ \\
\hline \multirow{2}{*}{ Commercial barley } & $4.22 \times 10^{-3}$ & $5.98 \times 10^{-4}$ & $5.01 \times 10^{-4}$ & $5.32 \times 10^{-3}$ & $1.90 \times 10^{-6}$ \\
& $\left(2.15 \times 10^{-2}\right)$ & $\left(9.15 \times 10^{-4}\right)$ & $\left(1.20 \times 10^{-3}\right)$ & $\left(2.36 \times 10^{-2}\right)$ & $\left(9.66 \times 10^{-6}\right)$ \\
\hline
\end{tabular}

$\S$ Maximum value of $\mathrm{HQ}$ and $\mathrm{CR}$

mated that dry soil condition promoted the absorption of $\mathrm{Cd}$ [8]. The mean and range of the $\mathrm{BCF}$ of $\mathrm{Pb}$ were 0.002 and $0.001-0.00$, respectively, similar to those of brown rice. The BCF for each element of barley was high in copper $(\mathrm{Cu})$, zinc $(\mathrm{Zn})$, and $\mathrm{Cd}$, and low in As and $\mathrm{Pb}$. This was similar to the previous results of reporting the BCF of leafy vegetables and medicinal crops in order of $\mathrm{Cd}>\mathrm{Zn}>\mathrm{Cu}>\mathrm{Pb}>\mathrm{As}>$ chromium $(\mathrm{Cr})$ $[15,16]$.

Table 5 shows the hazard quotients (HQ) and cancer risks (CR) for the monitored results of $\mathrm{As}, \mathrm{Cd}$ and $\mathrm{Pb}$ in barley were determined in this survey. The calculation result of non-carcinogenic hazard for each component was below 1, which was very unlikely to cause cancer through barley. In addition, the combined results of $\mathrm{As}, \mathrm{Cd}$ and $\mathrm{Pb}$ were $6.76 \times 10^{-2}$. CR risks averaged 2.06 $\times 10^{-6}$, and a maximum value of $9.50 \times 10^{-6}$, below the acceptable level of $10^{-4}$. The level of non-carcinogenic and carcinogenic hazards of market barley was also lower than that of the barley samples collected in the major producing districts.

\section{Conclusion}

This study was carried out to understand the characteristics of the transition of heavy metal(loid)s into soil-plant and to derive appropriate management practices for production of safe agricultural products. The soil and barley samples were collected from 38 locations around the major producing districts at Jeollabuk in Korea to examine the concentrations of heavy metal(loid)s. Separately, 34 barley samples were purchased on the market for the same survey. The $\mathrm{Pb}$ concentration of barley purchased at the market did not exceed the maximum allowable level of $0.2 \mathrm{mg} / \mathrm{kg}$ designated by the Food Sanitation Act. However, the Pb level exceeded the acceptable level at some sample of barley produced in the major producing districts.
Therefore, the agricultural safety management in barley must be considered to have been carried out from the production stage. Furthermore, it is assumed that $\mathrm{Pb}$ from other factors than soil may have been introduced among barley, and it is assumed that studies related to the physiological characteristics of agricultural materials and crops that affect the absorption of $\mathrm{Pb}$ crops should be carried out.

\section{Note}

The authors declare no conflict of interest

\section{Acknowledgement}

This study was carried out with the support of Cooperative Research Program for Agricultural Science \& Technology Development (Project No. PJ013392\&PJ01 364103), Rural Development Administration, Republic of Korea.

\section{References}

1. Newton AC, Flavell AJ, George TS, Leat P, Mullholland B, Ramsay L, Revoredo-Giha C, Russell J, Steffenson BJ et al. (2011) Crops that feed the world 4. Barley: a resilient crop? Strengths and weaknesses in the context. Food Security, 3(2), 141-178. https:// doi.org/10.1007/s12571-011-0126-3.

2. Zerrouki D, Maatoug $M$, Hellal B, Ait Hammou M (2013) Phytoremediation of contaminated agricultural soil by lead from traffic pollution using a common barley Hordeum vulgare. Intenational Journal Environment and Resource, 2(3), 49-57.

3. Kim JY, Lee JH, Kunhikrishnan A, Kang DW, Kim MJ, Yoo JH, Kim DH, Lee YJ, Kim WI (2012) Transfer factor of heavy metals from agricultural soil to agricultural products. Korean Journal of Environmental 
Agriculture, 31(4), 300-307.

https: / / doi.org/10.5338/KJEA.2012.31.4.300.

4. Kim WI, Kim JK, Yoo JH, Paik MK, Park SW, Kwon OK, Hong MK, Yang JE, Kim JG (2009) Risk assessment of $\mathrm{As}, \mathrm{Cd}, \mathrm{Cu}$ and $\mathrm{Pb}$ in different rice varieties grown on the contaminated soil. Korean Journal of Soil Science Fertilizer, 42(1), 53-57.

5. Lee JH, Kim WI, Jeong EJ, Yoo JH, Kim JY, Lee JB, Im GJ, Hong MK (2011) Assessment of health risk associated with arsenic exposure from soil, groundwater, polished rice for setting target cleanup level nearby abandoned mines. Korean Journal of Soil Science Fertilizer, 44(1), 38-47.

https: / / doi.org/10.7745.KJSSF.2011.44.1.038.

6. Mondal D, Polya D (2008) Rice in a major exposure route for arsenic in Chakdaha block, Nadia district, West Bengal, India: A probabilistic risk assessment. Applied Geochemistry, 23, 2987-2998. https: / / doi.org/10.1016/j.apgeochem.2008.06.025,

7. Kunhikrishnan A, Go WR, Park JH, Kim KR, Kim HS, Kim KH, Kim WI, Cho NJ (2015) Heavy metal(loid) levels in paddy soils and brown rice in Korea. Korean Journal of Soil Science Fertilizer, 48(5), 515-521.

https: / / dx.doi.org/10.7745/KJSSF.2015.48.5.515.

8. Kim JY, Kunhikrishnan A, Kim HS, Kim DY, Moon BC, Kim JG, Kim WI (2018) Impact of water management on arsenic and cadmium accumulation in rice grown nearby abandoned mines in Korea. Korean Journal of Soil Science Fertilizer, 51(4), 353-359. https: / / doi.org/10.7745/ KJSSF.2018.51.4.353.

9. Arao T, Kawasaki A, Baba K, Mori S, Matsumoto S (2009) Effects of water management on cadmium and arsenic accumulation and dimethylarsinic acid concentrations in Japanese rice. Environment Science Technology, 43, 9361-9367. https: / / doi.org/10.1021/es9022738.

10. Hu P, Li Z, Yuan C, Ouyang Y, Zhou L, Huang J, Huang
Y, Luo Y, Christie P, Wu L (2013) Effect of water management on cadmium and arsenic accumulation by rice (Oryza sativa L.) with different metal accumulation capacities. Journal of Soils and Sediments, 13, 916-924. https: / / doi.org/10.1007/s11368-013-0658-6.

11. Stanišić Stojića SM, Ignjatovića LM, Popovb S, Škrivanjc S, ĐorĐevićd AR, Stojiće A (2014) Heavy metal accumulation in wheat and barley: The effects of soil presence and liquid manure amendment. Plant Biosystems, 150(1), 104-110. https: / / doi.org/10.1080/11263504. 2014.976288.

12. Kim HS, Kim KR, Kim WI, Owens G, Kim KH (2017) Influence of road proximity on the concentrations of heavy metals in Korean urban agricultural soils and crops. Archives of Environmental Contamination and Toxicology, 72, 260-268. https: / / doi.org/10.1007/ s00244-016-0344-y.

13. Lee MN, Kim NK, Kim KR (2020) Identification of automobile-derived heavy metal(loid)s possibly loaded to soils through air dust deposit. Korean Journal of Soil Science Fertilizer, 53(4), 558-565. https: / / doi.org/10.7745/KJSSF.2020.53.4.558.

14. Wieczorek J, Wieczorek Z, Bieniaszewski T (2005) Cadmium ad lead content in cereal grains and soil from cropland adjacent to roadways. Polish Jouranl of Environmental Studies, 14(4), 535-540.

15. Wang Y, Qiao M, Liu Y, Zhu Y (2012) Health risk assessment of heavy metals in soils and vegetables from wastewater irrigated area, Beijing-Tianjin city cluster, China. Jouranl of Environmental Sciences, 24(4), 690-698. https: / / doi.org/10.1016/S1001-0742(11)60833-4.

16. Kim DY, Kim DI, Seo YJ, Choi SK, Kim KR, Kim KH, Kwon OK, Kim WI (2019) Transition characteristics and risk assessment of heavy metal(loid)s in Angelica gigas Nakai and Cnidium officinale Makino. Korean Journal of Soil Science Fertilizer, 52(4), 420-428. https: / / doi.org/10.7745/KJSSF.2019.52.4.420. 